Jahangirnagar University J. Biol. Sci. 4(1): 9-18, 2015 (June)

\title{
Analgesic, anti-inflammatory, anticonvulsant and CNS effect of the ethanolic extract of Butea monosperma roots
}

\author{
Shah Md. Anisul Arefin, Md. Alimul Islam, Syeda Tahmina Binte Rashid, Md. Abu \\ Rayhan, Md. Monir Hossen, Md. Jahir Alam ${ }^{1}$ and Masum Shahriar ${ }^{1 *}$ \\ Department of Pharmacy. Gono Bishwabidyalay, Savar, Dhaka-1344, Bangladesh
}

\begin{abstract}
The analgesic, anti-inflammatory, anticonvulsant and CNS activities of the ethanolic extract of Butea monosperma roots were examined. The extract produced no significant inhibition of abdominal constrictions caused by acetic acid. It showed significant inhibition of the earlyphase of formalin-induced pain, also reduced the weight of granuloma induced by a cotton pellet. Moreover, the extract caused a moderate inhibition of ear swelling in mice caused by croton oil. In pentobarbital induced sleeping time test the extract slightly reduced the onset and increased the duration of sleeping. Therefore, Butea monosperma showed analgesic, antiinflammatory, mild anticonvulsant activities as well as sedative effect on CNS.
\end{abstract}

Key words: Butea monosperma extract, analgesic, antiinflammatory, and anticanvubsive effect.

\section{INTRODUCTION}

Inflammation is a complex biological response of vascular tissues to harmful stimuli such as pathogens, damaged cells or irritants (physical or chemical). It is also the protective attempt by the organism to the injurious stimuli as well as initiate healing process for the tissue and considered to be the major cause of rheumatoid arthritis (Fayyaz et al., 1994; Divya et al., 2009). The inflammatory response can lead different diseases, such as rheumatoid arthritis, inflammatory bowel disease, psoriasis. Pain is a sensorial modality, primarily protective in nature, but often causes discomfort. It is the most important symptom that brings the patient to physician. Analgesics relieve symptoms of pain, but hardly affect its underlying cause (Goldsby et al., 2003). Convulsion is a medical condition where body muscles contract and relax rapidly and repeatedly resulting in an uncontrolled shaking of the body. The anticonvulsants (also commonly known as antiepileptic drugs) are drugs used in the treatment of epileptic seizure. The current therapy of epilepsy with modern antiepileptic drugs is associated with side effects, doserelated and chronic toxicity, as well as teratogenic effects, and approximately $30 \%$ of the patients continue to have seizures with current antiepileptic drugs therapy (Mattson, 1995; SamrJn et al., 1997).

Herbal medicines derived from the plant extracts are being increasingly utilized to treat a wide variety of clinical diseases, though relatively little knowledge about their mode of

\footnotetext{
${ }^{1}$ Department of Pharmacy, Jahangirnagar University, Savar, Dhaka-1342, Bangladesh

* Corresponding author. Email: masum_shahriar@juniv.edu
} 
action is available. The biodiversity of flora of Bangladesh is very broad, and several native Bangladeshi medicinal plant species have a long tradition of use with great phytotherapeutic potential (Karunakar, 2009). Thus, a scientific evaluation of herbs according to their traditional methods of use in various diseases management safely and more efficaciously can incorporate into the complementary and alter-native medicine (CAM) system elsewhere.

Butea monosperma is a species of Butea native to tropical and sub-tropical parts of the Indian subcontinent and Southeast Asia, ranging across India, Bangladesh, Nepal, Sri Lanka, Myanmar, Thailand, Laos, Cambodia, Vietnam, Malaysia and western Indonesia. It is an erect, medium-sized, $12-15 \mathrm{~m}$ high, deciduous tree with a crooked trunk and irregular branches. The main phytoconstituents of B. monosperma are butrin (1.5\%), butein $(0.37 \%)$ and butin (0.04\%) (Mishra \& Lavhale, 2007). Triterpene, butrin, isobutrin, coreopsin, isocoreopsin, sulphurein, monospermoside, isomonospermoside, chalcones, aurones, flavonoids and steroids are other phytoconstituents present in the flower (Gupta et al., 1970; Singh et al., 1974). B. monosperma is traditionally used as antioxidant, memory and behaviour stimulant, antileprotic, anticonvulsant, anti-inflammatory, antigout, antiulcer, antistress, astringent diuretic, antihepatotoxic, menstrual disturbances, enlarged spleen, antitumor, antidiabetic, burning sensation and eye diseases. It is also used in flatulent colic, cough and cold, liver disorders, gonorrhoea, night blindness, elephantiasis, impotency and in snake bite (Kirtikar \& Basu, 1935; Kala, 2004). The aim of the present study was to evaluate the analgesic, antiinflammatory anticonvulsant as well as CNS effect of $B$. monosperma root extract in animal model.

\section{MATERIALS AND METHODS}

Plant materials collection and preparation of sample: Butea monosperma was collected from Dhamrai area, Dhaka, Bangladesh. The plant species was taxonomically identified and authenticated by the Bangladesh National Herbarium, Mirpur, Dhaka. The collected materials were shed dried at $35^{\circ}-40^{\circ} \mathrm{C}$ for a week and crushed into moderately coarse powder. One $\mathrm{kg}$ of Butea monosperma powder was taken in soxhlet apparatus with $4000 \mathrm{ml} 80 \%$ ethanol and the solvent washing the constituents of $B$. monosperma powder was collected in a container, dried with a rotary evaporator under reduced pressure to get viscous substances. Finally, freeze-drier was used and ethanolic extract was obtained.

Experimental Animals: The study was conducted with adult Swiss Albino mice (weighing 25-30g) of either sex. They were bred at the Jahangirnagar University animal house maintained at a constant room temperature of $22 \pm 5^{\circ} \mathrm{C}, 40-70 \%$ humidity conditions and the natural day-night cycle with an ad libitum access to food except the day of experimental procedure when animals were used after $12 \mathrm{hrs}$ fasting. The rats had no access to food during the whole period of blood sampling. All protocols for animal experiment were approved by the institutional animal ethical committee following the "Revised guide for the care and use of laboratory animals by American Physiological Society"(Bayne, 1996). 
Toxicity studies: Toxicity studies of the Butea monosperma extract was carried out in Swiss Albino mice of either sex weighing between 20 and $25 \mathrm{~g}$. The extract was found to be safe till $4000 \mathrm{mg} / \mathrm{kg}$ p.o (Kim et al., 2006).

Experimental Design: Animals were divided into four groups of eight animals each. Group distribution and administered substance with their dose was as follows:

Group I: Control (Distilled water/normal saline, $100 \mathrm{mg} / \mathrm{kg}$ b.w.)

Group II: Standard (Specific to the model)

Group III: Butea monosperma extract (BM $600 \mathrm{mg} / \mathrm{kg}$ b.w.)

Group IV: Butea monosperma extract (BM $800 \mathrm{mg} / \mathrm{kg}$ b.w.)

All doses were administered per orally.

\section{Analgesic activity evaluation}

Acetic acid induced writhing test: The method according to Koster et al. (1959) was employed for this test. Four groups of eight mice each were pretreated with the Butea monosperma, Ethanolic extract (600 mg/kg and $800 \mathrm{mg} / \mathrm{kg}$ ) Diclofenac-Na $(100 \mathrm{mg} / \mathrm{kg}$ ) and normal saline $(10 \mathrm{~mL} / \mathrm{kg})$ respectively. Forty five minutes later each mouse was injected with $0.7 \%$ acetic acid at a dose of $10 \mathrm{~mL} / \mathrm{kg}$ body weight. The number of writhing responses was recorded for each animal during a subsequent 5 min period after 15 min of the I.P. administration of Acetic acid and the mean abdominal writhes for each group was obtained (Koster et. al., 1959).

Formalin-induced Paw licking test: The method of Hunskaar \& Hole (1987) was used for the study. Mice were divided into 4 groups of 8 animals each. Group 1, the control group received normal saline, p.o., group 2, the standard group received Diclofenac-Na $(100 \mathrm{mg} / \mathrm{kg})$. Groups 3, 4, received Ethanolic extract $(600 \mathrm{mg} / \mathrm{kg}$ and $800 \mathrm{mg} / \mathrm{kg})$. After 1 hour of drug administration, $2.7 \%$ formalin was injected into the dorsal surface of the left hind paw. The time spent licking the injected paw was recorded. Animals were observed for the $5 \mathrm{~min}$ post formalin (acute phase) and for $5 \mathrm{~min}$ starting at 20th min post formalin (delayed phase) (Hunskaar \& Hole, 1987).

\section{Anti-inflammatory activity evaluation}

Cotton pellet-induced granuloma formation test: The method of Swingle \& Shideman (1972) was used. Sterilized cotton pellets of $40 \pm 1 \mathrm{mg}$ of each weight were impregnated subcutaneously, one on each side of the abdomen of the animal, under light chloroform anesthesia and sterile technique. Test drugs were administered orally to male rate weighing 100-170 g in once-daily dose regimen for 7 days; the control group received vehicle only. The rat were sacrificed at the 8 th day $\&$ removed cotton pellets $\&$ dried at $60^{\circ} \mathrm{C}$ for $24 \mathrm{hrs} \&$ weighed dry cotton weight (Swingle \& Shideman, 1972). The lowering of the weight of cotton pellet indicates the inhibition of inflammation. 
Croton oil induced ear edema test: The croton oil induced ear edema test was performed as described Zitterl-Eglseer et al. (1997). Mice were divided into 4 groups of 8 animals each. Group 1, the control group received normal saline, p.o., group 2, the standard group received Diclofenac-Na $(100 \mathrm{mg} / \mathrm{kg})$. Groups 3, 4 received Ethanolic extract $(600 \mathrm{mg} / \mathrm{kg}$ and $800 \mathrm{mg} / \mathrm{kg}$ ). One hour later, each animal received $15 \mu \mathrm{l}$ of croton oil on the posterior surfaces of the right ear lobe and $15 \mu$ acetone on the inner surface of left ear lobe. Mice were sacrificed one hour after croton oil application and circular sections were taken, using a cork borer with a diameter of $3 \mathrm{~mm}$, and weighed (ZitterlEglseer et al., 1997).

\section{Anticonvulsant activity evaluation}

Pentylene Tetrazole induced convulsion test: A $60-\mathrm{mg} / \mathrm{kg}$ dose of PTZ was administered intraperitoneally $30 \mathrm{~min}$ after the intraperitoneal or subcutaneous injection of the plant extract to mice that were grouped into eight $(n=8)$. Latencies to the onset of seizures or hind limb tonic extension and the mortality were evaluated during $30 \mathrm{~min}$ after PTZ injection (Swinyard \& Kupferberg, 1985). Control animals were administered with vehicle.

Pentobarbital induced sleeping time: Mice were randomly divided into four groups. Control animals were treated with the vehicle. Mice in groups II received diazepam (1 $\mathrm{mg} / \mathrm{kg}$, i.p.). Group III-IV were treated with the test extract $(600,800 \mathrm{mg} / \mathrm{kg}$, p.o.). These treatments were carried out $30 \mathrm{~min}$ before the administration of pentobarbtal sodium ( 40 $\mathrm{mg} / \mathrm{kg}$, i.p.) to all the groups. Each mouse was observed for the onset (latency) of sleep and the duration of sleep using the loss of righting reflexes as the criterion for onset of sleep and the duration of sleep or hypnosis as the time the animal presented a loss of postural reflexes (Miya et al., 1973).

Statistical Analysis: Microsoft Office Excel (2007) was used as a statistical tool for inflammation and analgesia inhibition assay data. Statistical analysis for animal experiments was carried out using Independent-Sample T Test using SPSS 20 for windows. Data were presented as Mean \pm SEM. The results obtained were compared with the vehicle control group. $p$ values $<0.05,<0.01$ and $<0.001$ were considered to be statistically significant, highly significant and very highly significant, respectively.

\section{RESULT AND DISCUSSION}

In traditional system of medicine, certain plants are claimed to provide relief of pain and inflammation. Different parts of Butea monosperma are used by traditional practitioner for their anti-inflammatory, anticonvulsant, antiulcer, antitumor, antimicrobial, antifungal, antipyretic, blood purifier and anti-asthmatic properties.

The analgesic and anti-inflammatory effects of the ethanol extract were investigated in the present study. The analgesic activities were evaluated by chemically induced tissue damage animal models, which could provide response to two different grades of noxious stimuli (Victor et al., 2004). Acetic acid causes an increase in peritoneal fluids of PGE2 and PGF2 $\alpha$, serotonin and histamine involved in part, which is a model commonly used for screening peripheral analgesics (Derardt et al., 1980, Collier et al., 1968). 
Table 1. Effect of Butea monosperma (Roots) on the acetic acid induced writhing Test

\begin{tabular}{c|c|c|c|c}
\hline Group & $\begin{array}{c}\text { No. of writhing } \\
(\text { Mean } \pm \text { SEM) }\end{array}$ & t/p value & $\begin{array}{c}95 \% \text { confidence } \\
\text { interval }\end{array}$ & $\begin{array}{c}\text { \% inhibition of } \\
\text { algesia }\end{array}$ \\
\hline Con & $9.75 \pm 1.42$ & & 00 \\
Std & $7.25 \pm 1.84$ & $1.08 / 0.301$ & -2.489 to 7.49 & 34.48 \\
(Diclofenac-Na) & & & & \\
BM 600 mg & $9.70 \pm 1.86$ & $-0.82 / 0.427$ & -7.25 to 3.25 & 0.52 \\
BM 800 mg & $9.50 \pm 1.99$ & $-0.37 / 0.714$ & -5.90 to 4.15 & 2.63 \\
\hline
\end{tabular}

N.B $: *(<0.05)=$ Significant, $* *(<0.01)=$ Highly Significant, $* * *(<0.001)=$ Very Highly Significant. $(\mathrm{n}=$ $8)$.

With respect to the acetic acid-induced abdominal writhing which is the visceral pain model (Vyklicky, 1979), the result presented in table-1 showed that the alcoholic extract of root of BM have no ability to inhibit the number of writhes induced by administration of acetic acid when compared to the control. Diclofenac at $100 \mathrm{mg} / \mathrm{kg}$ exhibited strong inhibition of writhing. Local peritoneal receptors are postulated to be involved in the abdominal constrictions response (Bentley et al., 1983). The result of this study suggests that root extract of BM perhaps have no peripheral analgesic effect which is mediated via the inhibition of synthesis and release of PGs and other endogenous substances.

Formalin test is believed to be a more valid analgesic model which is better correlated with clinical pain (Tjolsen et al., 1992, Ghannadi et al., 2005). Formalin test is biphasic, and measures pain of both neurogenic (first phase) and of inflammatory origin (second phase). The first phase $(0-5 \mathrm{~min})$ being a result of direct stimulation of nociceptors measures centrally mediated effects and is insensitive to anti-inflammatory agents while the second phase $(15-30 \mathrm{~min})$ is dependent on peripheral inflammation and changes in central procession due to chemical mediators release from damaged cells that stimulate nociception and thus induced pain (Hunskaar, \& Hole, 1987). Ethanolic extract of BM caused a decrease in licking time and licking frequency by the mice injected with formalin which is more pronounced at late phase (Table 2, 3). The suppression of both phases as observed in the dose tested in this study suggests the presence of both central and peripheral effects. However, the greater protection was at the late phase against the neurogenic pain.

Table 2. Effect of Butea monosperma (Roots) on the formalin induced paw licking Test $\left(1^{\text {st }} 5\right.$ minutes)

\begin{tabular}{l|c|c|c|c}
\hline \multicolumn{1}{c|}{ Group } & $\begin{array}{c}\text { Time of licking } \\
\text { (Mean } \pm \text { SEM) }\end{array}$ & t/p value & $\begin{array}{c}\text { 95\% confidence } \\
\text { interval }\end{array}$ & $\begin{array}{c}\text { \% inhibition } \\
\text { of algesia }\end{array}$ \\
\hline Con & $96.38 \pm 16.90$ & & 00 \\
Std (Diclofenac-Na) & $74.00 \pm 7.79$ & $2.15 / 0.049$ & 0.06 to 44.69 & 30.24 \\
BM 600 mg & $50.13 \pm 6.54$ & $4.87 / 0.000$ & 25.86 to 66.64 & 92.26 \\
BM 800 mg & $62.38 \pm 5.71$ & $3.80 / 0.002$ & 14.72 to 53.28 & 54.51 \\
\hline
\end{tabular}

N.B : $*(<0.05)=$ Significant, $* *(<0.01)=$ Highly Significant, $* * *(<0.001)=$ Very Highly Significant. $(\mathrm{n}=8)$ 
Table 3. Effect of Butea monosperma (Roots) on the formalin induced paw licking Test ( $2^{\text {nd }} 5$ minutes)

\begin{tabular}{c|c|c|c|c}
\hline Group & $\begin{array}{c}\text { Time of licking } \\
(\text { Mean } \pm \text { SEM) }\end{array}$ & t/p value & $\begin{array}{c}95 \% \text { confidence } \\
\text { interval }\end{array}$ & $\begin{array}{c}\text { \% inhibition } \\
\text { of algesia }\end{array}$ \\
\hline $\begin{array}{c}\text { Con } \\
\text { Std }\end{array}$ & $\begin{array}{c}\text { 37.25 } \pm 17.53 \\
\text { (Diclofenac-Na) }\end{array}$ & & & 00 \\
BM 600 mg & $45.88 \pm 8.16$ & $1.73 / 0.115$ & -9.77 to 76.52 & 98.50 \\
BM 800 mg & $31.50 \pm 6.75$ & $1.90 / 0.089$ & -4.77 to 6.52 & 47.38 \\
\hline
\end{tabular}

N.B : $*(<0.05)=$ Significant, $* *(<0.01)=$ Highly Significant, $* * *(<0.001)=$ Very Highly Significant. $(\mathrm{n}=$ $8)$.

Cotton pellet granuloma model was used to evaluate the antiinflammatory activity of Butea monosperma in sub acute inflammation. Three phases of the inflammatory response to a subcutaneously implanted cotton pellet in the rats have been described: (A) a transudative phase, that occurs during the first $3 \mathrm{~h}$; (B) an exudative phase, occurring between 3 and $72 \mathrm{~h}$ after implanting the pellet; (C) a proliferative phase, measured as the increase in dry weight of the granuloma that occurs between 3 and 6 days after implantation (Swingle \& Shideman, 1972). The suppression of proliferative phase of sub acute inflammation could result in decrease in the weight of granuloma formation (Kavimani et al., 1996). The dry weight of cotton pellet granuloma was reduced by (Table 4) administration of BM extract, and the antiproliferative effect of BM was comparable to that of the standard drug.

Table 4. Effect of Butea monosperma (Roots) on cotton pellet induced granuloma test

\begin{tabular}{c|c|c|c|c}
\hline Group & $\begin{array}{c}\text { Weight of dry cotton } \\
\text { (Mean } \pm \text { SEM) }\end{array}$ & t/p value & $\begin{array}{c}95 \% \text { confidence } \\
\text { interval }\end{array}$ & $\begin{array}{c}\% \text { inhibition of } \\
\text { inflammation }\end{array}$ \\
\hline Con & $0.17 \pm 0.00$ & & 00 \\
Std & $0.15 \pm 0.00$ & $4.57 / 0.002$ & 0.01 to 0.02 & 13.33 \\
(Ibuprofen) & & & & \\
BM 600 mg & $0.14 \pm 0.01$ & $2.25 / 0.055$ & -0.00 to 0.05 & 21.43 \\
BM 800 mg & $0.15 \pm 0.01$ & $2.62 / 0.030$ & 0.00 to 0.04 & 13.33 \\
\hline
\end{tabular}

N.B $: *(<0.05)=$ Significant, $* *(<0.01)=$ Highly Significant, $* * *(<0.001)=$ Very Highly Significant. $(\mathrm{n}=$ $8)$.

The application of mouse models of ear edema induced by different irritant agents (Croton oil, xylene, capsaicin, AA, phenol, histamine) has been widely used to identify the probable topical anti-inflammatory effect of the substance in study and to propose its possible mechanism of action (Gábor, 2000). Croton oil contains TPA as main irritant agents which is able to activate protein kinase $\mathrm{C}$ (PKC), which activates other enzymatic cascades in turn, leading to release of platelet activation factor (PAF) and AA. This cascade of events stimulates vascular permeability, vasodilation, polymorphonuclear leukocytes migration, release of histamine and serotonin and moderate synthesis of inflammatory eicosanoids by cyclooxygenase (COX) and 5-lipoxygenase (5-LOX) 
enzymes (Ferrandiz et al., 1996; Wang et al., 2001). As shown in able 5, ethanolic extract of BM $(800 \mathrm{mg} / \mathrm{kg}$, p.o. $)$ markedly inhibited the ear inflammation caused by croton oil.

Epilepsy is a neurological disorder of brain characterized by unpredictable and periodic occurrence of a transient alteration of behavior due to the disordered, synchronous and rhythmic firing of populations of brain neurons (Cockerel et al., 1995). As there are some reports suggested that extract of Butea monosperma leaves possess anticonvulsant property, anticonvulsant potential of root extract was also evaluated in chemically induced seizures in mice.

Pentylene tetrazole (PTZ) is the most frequently used substance in a preliminary screening to test potential anticonvulsant drugs (Swinyard \& Kupferberg, 1985). PTZ induces convulsions by inhibiting the GABA pathway (Corda et al., 1990). Drugs protecting against seizures induced by PTZ, reduce T-type calcium currents (Murali et al., 2008) and are considered to be useful for control of myoclonic and absence seizures (Nisar et al., 2009).

Table 5. Effect of Butea monosperma (Roots) on croton oil induced ear edema test

\begin{tabular}{c|c|c|c|c}
\hline Group & $\begin{array}{c}\text { \% of inflammation } \\
(\text { Mean } \pm \text { SEM })\end{array}$ & t/p value & $\begin{array}{c}\text { 95\% confidence } \\
\text { interval }\end{array}$ & $\begin{array}{c}\text { \% inhibition of } \\
\text { inflammation }\end{array}$ \\
\hline Con & $48.16 \pm 5.42$ & & \\
Std & $42.56 \pm 5.57$ & $0.71 / .489$ & -11.15 to 22.34 & 13.16 \\
(Diclofenac-Na) & & & & \\
BM 600 mg & $43.63 \pm 3.26$ & $0.09 / .932$ & -12.31 to 13.35 & 14.11 \\
BM 800 mg & $35.42 \pm 6.90$ & $0.30 / .769$ & -16.64 to 22.10 & 6.03 \\
\hline
\end{tabular}

N.B $: *(<0.05)=$ Significant, $* *(<0.01)=$ Highly Significant, $* * *(<0.001)=$ Very Highly Significant. $(\mathrm{n}=$ $8)$.

In the PTZ model, administration of root extract of BM (600, and $800 \mathrm{mg} / \mathrm{kg}$, i.p.) slightly increased onset time for PTZ-induced seizures. BM could suppress onset and duration (Table 6) of clonic seizure in PTZ model and it seems that this effect increased dose dependently.

Table 6. Effect of Butea monosperma (Roots) on Pentylene tetrazole induced convulsion test

\begin{tabular}{c|c|c|c}
\hline Group & $\begin{array}{c}\text { Onset of Convulsion }(\mathrm{Sec}) \\
(\text { Mean } \pm \text { SEM) }\end{array}$ & $\mathrm{t} / \mathrm{p}$ value & $\begin{array}{c}\text { 95\% confidence } \\
\text { interval }\end{array}$ \\
\hline Con $(\mathrm{n}=10)$ & $\begin{array}{c}621.57 \pm 175.49 \\
\text { No convulsion }\end{array}$ & \\
Std & $767.11 \pm 110.92$ & $-0.732 / 0.476$ & -571.98 to 280.90 \\
P600 mg $(\mathrm{n}=10)$ & $1024.12 \pm 128.01$ & $-1.886 / 0.082$ & -863.67 to 58.56 \\
P800 mg $(\mathrm{n}=10)$ &
\end{tabular}

N.B $: *(<0.05)=$ Significant, $* *(<0.01)=$ Highly Significant, $* * *(<0.001)=$ Very Highly Significant. $(\mathrm{n}=$ $6)$.

Pentobarbital, a member of the barbiturate group of sedative- hypnotic, due to its ability to depress the limbic system and the reticular activating system, can induce sleep. The possible potentiating effects of BM to such effect of a sedative-hypnotics was 
investigated in the experiment on pentobarbital sleeping time. Administration of BM root extract dose dependently potentiated the sleep induced by pentobarbital suggesting that the root of the plant possess sleep inducing property (Table 7). Pentobarbital, a hypnotic agent, when given at appropriate dose, induces sedation or hypnosis by potentiating GABA mediated postsynaptic inhibition through allosteric modification of GABA receptors. The prolongation of pentobarbital-induced sleeping time may be attributed to an inhibition of pentobarital metabolism or to an action on the central mechanism involved in the regulation of sleep.

Table 7. Effect of Butea monosperma (Roots) on Pentobarbital induced sleeping time

\begin{tabular}{c|c|c|c}
\hline Group & $\begin{array}{c}\text { Sleeping Time }(\mathrm{Sec}) \\
(\text { Mean } \pm \text { SEM) }\end{array}$ & t/p value & 95\% confidence interval \\
\hline Con & $4162.50 \pm 446.25$ & & \\
P600 mg & $5357.43 \pm 399.66$ & $-1.995 / 0.073$ & -2520.01 to 130.15 \\
P800 mg & $6092.88 \pm 373.37$ & $-3.318 / 0.007$ & -3215.35 to -645.40 \\
\hline
\end{tabular}

N.B $: *(<0.05)=$ Significant, $* *(<0.01)=$ Highly Significant, $* * *(<0.001)=$ Very Highly Significant. $(\mathrm{n}=$ $8)$.

The results obtained in this study indicate that Butea monosperma root extracts possess weak analgesic properties, which are mediated via peripheral and central inhibitory mechanisms. The extracts showed good activity against acute and especially chronic inflammation. Our result showed that Butea monosperma possesses little anticonvulsant activity probably due to the active constituents present in the extract either inability to modulation of GABAergic system or reduction of neuronal excitability mainly through the voltage-dependent $\mathrm{Na}^{+}$channels. However, the extract showed sedative properties. Future study should focus on the identification of exact mechanisms of action of Butea monosperma for the potential CNS modulating properties using different animal models.

\section{REFERENCES}

Bentley, G.A., Newton, S.H. and Starr, J. 1983. Studies on the Anti-nociceptive Action of Agonist Drugs and their Interaction with Opioid Mechanisms. Br J Pharmacol. 79: 125 -134.

Bayne, K. 1996.Revised Guide for the Care and Use of Laboratory Animals available. American Physiological Society. Physiologist. 39(4):199-208

Cockerel, O.C., Johnson, L., Sander, J.W.A., Hart, Y.M. and Shorvon, D.S. 1995. Remission of epilepsy: results from the National General Practice Study of Epilepsy. Lancet. 346: 140 144.

Collier, H. O. J., Dinneen, L. C., Johnson, C. A. and Schneider, C. 1968. The abdominal constriction response and its suppression by analgesic drugs in the mouse. Br. J. Pharmcol. 32:295-310.

Corda, M.G., Giorgi, O., Longoni, B., Orlandi, M. and Biggio, G., 1990. Decrease in the function of the gamma aminobutyric acid-coupled chloride channel produced by the repeated administration of pentylenetetrazol to rats. Journal of Neurochemistry. 55: 1221-1261

Derardt, R., Jongney, S., Delevalcee, F. and Falhout, M. 1980. Release of Prostaglandin E and F in an analgesic Reaction and its Inhibition. Eur J Pharmacol. 51: 17 -24.

Divya, T. S., Latha, P. G., Usha, K., Anuja, G. I., Suja, S. R., Shyamol, S., Shine, V. J., Sini, S., Shikha, P. and Rajasekharan, S. 2009. Anti-inflammatory, analgesic and anti-lipid 
peroxidative properties of Wattakaka volubilis (Linn.f) Stapf. Nat Prod Rad. 8(2): 137141.

Fayyaz, A., Rafeeq, A. K. and Shahid, R. 1994. Preliminary screening of methanolic extracts of Celastrus paniculatus and Tecomella undulata for analgesic and anti-inflammatory activities. J. Ethnopharmacol. 42: 193-198.

Ferrandiz, M.L., Gil, B., Sanz, M.J., Ubeda, A., Erazo, S., González, E., Negrete, R., Pacheco, S., Paya, M. and Alcaraz, M.J., 1996. Effect of bakuchiol on leucoyte functions and some inflammatory responses in mice. Journal of Pharmacy and Pharmacology. 48: 975-980.

Gábor, M. 2000. Mouse Ear Inflammation Models and their Pharmacological Applications. Akadémiai Kiadó, Budapest. P 136.

Ghannadi, A., Hajhashemi, V. and Jafarabadi, H. 2005. An investigation of the analgesic and antiinflammatory effects of Nigella sativa seed polyphenols. J. Medicinal Food. 8: 488-493.

Goldsby, R. A., Kindt, T. J., Osborne, B. A. and Kuby, J. 2003. Immunology, 5th ed. Publication of W.H. Freeman and Company, New York, USA.

Gupta, S.R., Ravindranath, B. and Seshadri, T. 1970. The glucosides of Butea monosperma. Phytochemistry. 9(10): 2231-2235.

Hunskaar, S. and Hole, K. 1987. The formalin test in mice: dissociation between inflammatory and non-inflammatory pain. Pain. 30: 103-114.

Kim, Ji Su, Ju Jung Bong, Choi Chang Won and Kim Sei Chang. 2006. Hypoglycemic and antihyperlipidemic effect of four Korean Medicinal plants in alloxan induced diabetes rats. American Journal of Biochemistry \& Biotechnology. 2(4), p154-160.

Kala, C. 2004. Prioritization of medicinal plants on the basis of available knowledge, existing practices and use value status in Uttaranchal. India. Biodivers. and Conserv. 13: 459.

Karunakar, S. 2009. Bioassay: -An uncomplicated methodologies for ensure safety of Traditional Formulations. Research Journal of Pharmacognosy and Phytochemistry. 1(1):1-4.

Kirtikar, K.R. and Basu, B.D. 1935. Indian medicinal plants, Allahabad, India. Vol. I, 2nd edition, pp. 785-788.

Kavimani, S., Vetrichelvan, T., Ilango, R. and Jaykar, B. 1996. Antiinflammatory activity of the volatile oil of Toddalia asiatica. Indian J Pharm Sci. 58(2): 67-70.

Koster, R., Anderson, M. and De-Beer, E. J. 1959. Acetic acid analgesic screening. Fed Proc 18: $412-417$.

Mattson, R.H. 1995. Efficacy and adverse effects of established and new antiepileptic drugs. Epilepsia. 36 (2): S13-S26.

Mishra, S.H. and Lavhale, M.S. 2007. Evaluation of free radical scavenging activity of Butea monosperma Lam. Indian J Exp Biol. 45: 376-384.

Murali, G., Panneerselvam, K.S. and Panneerselvam, C. 2008. Age-associated alterations of lipofuscin, membrane-bound ATPases and intracellular calcium in cortex, striatum and hippocampus of rat brain: Protective role of glutathione monoester. Int J Dev Neurosci, 26, 211-215.

Miya, T.S., Holck, H.G.O., Yui, G.K.W. and Spratto, G.R. 1973. Laboratory guide in Pharmacology, Burgess Publishing Company, Minneapolis MN, pp. 44-46.

N'Gouemo, P., Baldy-Moulinier, M. and N'Guemby-Bina, C. 1994. Effects of an ethanolic extract of Desmodium adscendens on central nervous system in rodents. J Ethnopharmacol. 52, 77-83.

Nisar, M., Ahmad, M., Wadood, N., Lodhi, M.A., Shaheen, F. and Choudhary, M.I. 2009. New diterpenoid alkaloids from Aconitum heterophyllum Wall: Selective butyrylcholinestrase inhibitors. J Enzyme Inhib Med Chem. 24, 47-51.

SamrJn, E.B., van Duijn, C.M., Koch, S., Hiidesmaa, V.K., Klepel, H., Bardy, A.H., Mannagetta, G.B., Deichl, A.W., Gaily, E., Granstron, M.L., Meinardi, A.H., Grobbee, D.E., Hofman, A., Janz, D. and Lindhout, D. 1997. Maternal use of antiepileptic drugs and the risk of 
major congenital malformations : a joint European prospective study of human teratogenesis associated with material epilepsy. Epilepsia. 38: 981.

Singh, A.N., Upadhye, A.B., Mhaskar, V.V. and Dev, S. 1974. Components of soft resin. Tetrahedron 30(7): 867-874.

Swingle, K.F. and Shideman, F.E. 1972. Phases of the inflammatory response to subcutaneous implantation of a cotton pellet and their modification by certain anti-inflammatory agents. J Pharmacol Exp Ther. 185: 226-234.

Swinyard, E.A. and Kupferberg, H.J. 1985. Antiepileptic drugs: detection, quantification and evaluation. Federal Proceedings. 44: 2629-2633.

Tjolsen, A., Gerge, O.G. and Hunskaar, S. et al. 1992. The formalin test: an evaluation of method. Pain. 51: 3-17.

Victor, B. O., Caleb, O. W., Ayodele, O. S. and Samuel, B. O. 2004. Studies on the Antiinflammatory and analgesic properties of Tithonia diversifolia leaf extract. J. Ethnopharmacol., 90, 317-321.

Vyklicky, L. 1979. Techniques for the study of pain in animals, In: Bonica, JJ, Liebeskin \& AlbeFessard, DG (Eds), Advances in Pain Research and Therapy. Raven. New York, USA. pp.773-778.

Wang, H.Q., Kim, M.P., Tiano, H.F., Langenbach, R. and Smart, R.C. 2001. Protein kinase Calpha coordinately regulates cytosolic phospholipase A2 activity and the expression of ciclooxygenase-2 trought differtent mechanism in mouse keratinocytes. Molecular Pharmacology. 59: 860-866.

Zitterl-Eglseer, K., Sosa, S., Jurenitsch, J., Schubert-Zsilavecz, M., Della Loggia R., Tubaro, A., Bertoldi, M. and Franz, C. 1997. Anti-oedematous activities of the main triterpendiol esters of marigold (Calendula officinalis L.). J. Ethnopharmacol. 57: 139-144. 